\title{
Bills to counter terrorists
}

\section{Washlngton}

LEGISLATION that would make it a crime in the United States to make or stockpile biological agents that could be used as "weapons of mass destruction" seems set to be passed by Congress.

Bills in both the Senate and House of Representatives have attracted many sponsors and are expected to be voted on this year.

The legislation is intended to implement the 1972 Biological Weapons Convention, the treaty banning the development of biological weapons signed by 103 nations including the Soviet Union. The United States ratified the treaty, but the lack of political support for arms control in the late 1970 s and early 1980 s made it difficult for Congress to pass criminal legislation outlawing biological weapons. Current concerns over possible terrorist activities have now convinced Congress that such laws are needed.

The Bush Administration also supports the idea. Ambassador H. Allan Holmes, now Assistant Secretary of State, said at a congressional hearing last week that there is no evidence that any specific group or country is developing biological weapons, but that approximately ten countries have the capability to do so.

Ambassador James F. Leonard, one of the negotiators of the bioweapons treaty, says the law will create "confidence abroad" that the United States will follow up on treaty obligations - particularly important now because of current negotiations for a treaty banning chemical weapons.

Moves are also afoot to prove to other countries that the United States is not making biological weapons. Representative Wayne Owens (Democrat, Utah) last week tacked an amendment onto next year's defence spending bill requiring the military to publish annually a list of the biological agents it is using to develop defensive measures - allowed by the biowarfare treaty - in the event of an attack with biological weapons. A bill has also been introduced to transfer all biodefence research to the National Institutes of Health.

Both the current House and Senate bills specifically exempt research on biological agents "for prophylactic, protective, or other peaceful purposes". But they differ over whether the government must be able to prove malicious intent, or whether government officials will be able to seize and destroy suspect cultures, and ask questions later, leaving it up to an individual to prove they were performing legitimate research. Which side will carry the "burden of proof" will be decided in the next few weeks, with advice from the relevant federal agencies.

Carol Ezzell

\section{US - Soviet journal launch}

\section{San Franc/sco}

AFTER nearly seven years of planning and bureaucratic negotiations, a quarterly journal produced jointly by Soviet and US scientists is due out this month.

The main aim of Science \& Global Security is, according to editor Harold Feiveson, a senior research scientist at Princeton University, "to help foster, among scientists and other analysts, an open discussion on problems of arms control and global environmental issues".

The inaugural issue focuses on "space reactor arms control", and addresses such topics as infrared monitoring of nuclear power in space and the environmental hazards of space-based nuclear power.

The idea for the journal originated in 1983 with Evgenii Velikov, vice-president of the Soviet Academy of Sciences and former chairman of the Committee of Soviet Scientists for Peace and against the Nuclear Threat. Velikov sought out Princeton's Frank von Hippel as a US ally - with the goal of producing a technically strong, non-governmental publication that could be used as an archival base for future studies. At first, the idea was to focus on arms control and military issues, but the scope quickly broadened to include space and the environment.

The idea was developed further in the United States and the Soviet Union for at least two years, and was then delayed when the Soviets initially refused approval, says Feiveson. Velikov remains on the board of editors. His successor at the Committee of Soviet Scientists, Roald Sagdeev, joins von Hippel as co-chair of the 14-member editing board, which includes five Soviets and nine Americans.

It is too early to tell how much support the new journal is gathering. Joel Primack, a physics professor at the University of California, Santa Cruz, and the main author of the overview article on space reactors in the first issue, says the quarterly journal fills a vital niche. "There are a number of magazines for non-technical articles", he says, "but until this one was started I do not believe that there has been a technical journal where you can publish articles with equations and detailed analyses and footnotes and so forth."

Initial attempts to find a Soviet publisher have become bogged down, perhaps because of traditional wariness of 'political' issues, so a Soviet publisher is still being sought. But the journal will be published in English by Gordon and Breach Science Publishers.

Individual subscriptions, available through Gordon and Breach in either London or New York, cost $\$ 34$ or $£ 24$ a year.

Robert Buderl 